\title{
LEVEL OF METHIONINE SYNTHASE ACTIVITY AND INTERCONVERSION OF METHYLCOBALAMIN AND ADENOSYLCOBALAMIN IN A FACULTATIVE METHYLOTROPH, PROTAMINOBACTER RUBER
}

\author{
Kazuyoshi SATO and Shoichi SHIMIzU ${ }^{1}$ \\ Department of Food Science and Technology, Nagoya University, \\ Chikusa-ku, Nagoya 464, Japan
}

(Received June 28, 1980)

\begin{abstract}
Summary Protaminobacter ruber was cultured in a medium containing $\left[{ }^{57} \mathrm{Co}\right]$ cyanocobalamin with a "two-step cultivation method" and the forms of vitamin $\mathrm{B}_{12}$ compounds in the cells were examined. Methylcobalamin was detected in the early phases of growth and reached a maximum of about $40 \%$ of all cobalamins extracted from the cells. In the stationary phase of growth, almost all cobalamins consisted of adenosylcobalamin. Recultivation of the cells of the stationary phase in a fresh medium resulted in the conversion of adenosylcobalamin into methylcobalamin. Interconversion of methylcobalamin and adenosylcobalamin was presumed from these facts.

The formation of adenosylcobalamin from methylcobalamin was demonstrated with a cell-free extract system from $P$. ruber. The rate of conversion of methylcobalamin into adenosylcobalamin was highest among several cobalamin analogs tested. Propylation of 5-methyltetrahydrofolate: homocysteine methyltransferase with 1-iodopropane did not affect this conversion reaction, which was probably catalyzed by methyltransferase and adenosyltransferase.

Keywords Protaminobacter ruber, facultative methylotroph, methionine synthase, methylcobalamin, adenosylcobalamin, vitamin $\mathrm{B}_{12}$ interconversion
\end{abstract}

A facultative methylotroph, Protaminobacter ruber NR-1, produces methylcobalamin and adenosylcobalamin(1). We demonstrated that methylcobalamin participates in cobalamin-dependent methionine synthase [5-methyltetrahydropteroyl-L-glutamate: L-homocysteine $S$-methyltransferase, EC 2.1.1.13], while adeno-

佐藤一精, 清水祥一

Abbreviations: $\mathrm{B}_{12}$ is used to denote various cobalamins. CN-Cbl, cyanocobalamin; $\mathrm{MeCbl}$, methylcobalamin; OH-Cbl, hydroxocobalamin; AdoCbl, adenosylcobalamin; $\mathrm{FMNH}_{2}$, reduced riboflavin 5'-phosphate; SAM, $S$-adenosylmethionine; DTT, dithiothreitol. 
sylcobalamin participates in methylmalonyl-CoA mutase [methylmalonyl-CoA CoA carbonylmutase, EC 5.4.99.2] $(2,3)$ and glutamate mutase[D-threo-3-methylaspartate carboxyaminomethylmutase, EC 5.4.99.1] in the microorganism. The time course of the changes of the $\mathrm{B}_{12}$-forms in the cells during cultivation revealed that more methylcobalamin was produced at earlier phases of the bacterial growth, but after the late logarithmic phase almost all of the $\mathrm{B}_{12}$ compounds were present in the form of adenosylcobalamin (1).

On the other hand, sulfitocobalamin was isolated from partially purified methionine synthase from Escherichia coli $(4,5)$, and Taylor and Weissbach (6) proposed the existence of an inactive $(-\mathrm{S}-\mathrm{Co}) \mathrm{B}_{12}$ enzyme in the schematic reaction mechanism for $\mathrm{B}_{12}$-dependent methionine synthesis. If such an inactive enzyme exists in vivo, one of the $\mathrm{B}_{12}$ compounds extracted from the cells should be sulfitocobalamin or hydroxocobalamin. However, the forms of $\mathrm{B}_{12}$ compounds obtained from the cells of $P$. ruber were only methylcobalamin and adenosylcobalamin (2). Since other vitamin $B_{12}$ compounds might not have been extracted from the cells under the experimental conditions used, a more precise investigation would be required to definitely arrive at this conclusion. In addition, adenosylcobalamin was the predominant form in the stationary phase cells (2). This may represent the conversion from methylcobalamin into adenosylcobalamin. Thus, it is interesting to examine whether there are interconversions between methylcobalamin and adenosylcobalamin in the cells during the cultivation. The present study was designed to clarify these points.

\section{MATERIALS AND METHODS}

Chemicals. $\left[{ }^{14} \mathrm{C}\right]$ Methyl iodide, $5-\left[{ }^{14} \mathrm{C}\right]$ methyl-tetrahydrofolate and $\left[{ }^{57} \mathrm{Co}\right]-$ cyanocobalamin were purchased from the Japan Radioisotope Association. $S$-Adenosylmethionine was obtained from Kyowa Hakko Kogyo Co. Unlabeled 5methyltetrahydrofolate was prepared by the methods of Keresztesy and Donaldson (7). $\left[{ }^{14} \mathrm{C}\right]$ Methyl-cobalamin was synthesized as described by Smith et al. (8) and $\mathrm{FMNH}_{2}$ was prepared each day by the catalytic hydrogenation of FMN with $\mathrm{PtO}_{2}(9)$. Other reagents were of the best grade commercially available.

Organism and cultivation conditions. Protaminobacter ruber NR-1 was grown in a medium containing $2 \%$ methanol $(\mathrm{v} / \mathrm{v})$ as the sole carbon and energy source $(2,10)$, except for in vitro adenosylation experimentation in which the bacterium was cultured in a medium containing 1,2-propanediol (v/v) as the sole carbon and energy source $(2,10)$. The bacterium was grown by the following two methods. A) Conventional cultivation method: $0.5 \mathrm{ml}$ aliquots of seed culture grown for about two days (OD: $c a$. 6.0) were inoculated into $500 \mathrm{ml}$-Sakaguchi flasks containing $100 \mathrm{ml}$ of the medium and the flasks were shaken at $30^{\circ} \mathrm{C}$ on a reciprocating shaker operating at 150 strokes per min. B) The cultivation method that we call the "two-step cultivation method": The cells cultured by means of the conventional cultivation method were collected aseptically by centrifugation at 
$5,000 \times g$ for 20 min with sterilized, capped centrifuge tubes. The cells thus obtained were suspended in the same volume of the sterilized medium as that of the cultures. Fifty $\mathrm{ml}$ aliquots of the suspension were inoculated into Sakaguchi flasks containing $50 \mathrm{ml}$ of the sterilized medium or containing $50 \mathrm{ml}$ of the same sterilized medium except that $\left[{ }^{57} \mathrm{Co}\right]$ cyanocobalamin $\left(50 \mu \mathrm{g}, 4 \times 10^{5} \mathrm{cpm}\right)$ was added instead of cobaltous ion. The flasks were shaken at $30^{\circ} \mathrm{C}$ on the reciprocating shaker operating at 150 strokes per min. The bacterial growth was followed turbidimetrically at $660 \mathrm{~nm}$ (ADS) with an Akiyama D.S. 374 Fuji spectrophotometer. Optical density of the cultures was calculated by using the relationships between ADS and OD values obtained in separate experiments (3).

Preparation of cell-free extracts and assays. All the cells were stored at $-15^{\circ} \mathrm{C}$ until use. Cell-free extracts were prepared as described previously (1).

5-Methyltetrahydrofolate: homocysteine methyltransferase and methylcobalamin: homocysteine methyltransferase were assayed as previously described (1113). The reaction mixture for propylation of methionine synthase contained 1iodopropane $1 \mu \mathrm{mol}$, homocysteine $20 \mu \mathrm{mol}$, SAM $0.05 \mu \mathrm{mol}, \mathrm{FMNH}_{2} 0.4 \mu \mathrm{mol}$, potassium phosphate buffer ( $\mathrm{pH}$ 7.5) $100 \mu \mathrm{mol}$ and cell-free extracts (protein, $c a$. $5 \mathrm{mg})$ in a total volume of $1.5 \mathrm{ml}$. $\mathrm{FMNH}_{2}$ and 1-iodopropane $(40 \mu \mathrm{mol}$ per $\mathrm{ml}$ of $50 \%$ ethanol) in an atmosphere of $\mathrm{H}_{2}$ were added with syringes through serum rubber stoppers after the gas substitution into $\mathrm{H}_{2}$. As the control, $50 \%$ ethanol solution $(25 \mu \mathrm{l})$ was added instead of 1-iodopropane. The mixtures were incubated at $37^{\circ} \mathrm{C}$ for $2 \mathrm{hr}$ and dialyzed 3 times against 2 liters of $0.01 \mathrm{~m}$ potassium phosphate buffer for $40 \mathrm{hr}$ at $4^{\circ} \mathrm{C}$. Aliquots of the dialysate with or without light exposure (at $10 \mathrm{~cm}$, for $2 \mathrm{~min}$ with $200 \mathrm{~W}$ tungsten lamp) were used for enzymatic assays of methionine synthesis and adenosylation.

Adenosylating enzyme [ATP: $\operatorname{cob}(\mathrm{I})$ alamin Co- $\beta$-adenosyltransferase, EC 2.5.1.17] was assayed in the dark as follows. The standard reaction mixtures contained any one cobalamin analog $0.4 \mu \mathrm{mol}$, homocysteine $20 \mu \mathrm{mol}$ (omitted when hydroxocobalamin was used), ATP-Na 25 mol, $\mathrm{MgCl}_{2} 200 \mu \mathrm{mol}, \mathrm{KCl}$ $200 \mu \mathrm{mol}$, DTT $10 \mu \mathrm{mol}, \mathrm{FMNH}_{2} 0.2 \mu \mathrm{mol}$, Tris- $\mathrm{HCl}$ buffer (pH 7.5) $300 \mu \mathrm{mol}$ and cell-free extracts (protein 2-5 mg) in a total volume of $2.0 \mathrm{ml} . \mathrm{FMNH}_{2}$ was added with a syringe through a serum rubber stopper after gas substitution into $\mathrm{H}_{2}$. The reaction was terminated by adding $0.5 \mathrm{ml}$ of $1 \mathrm{~N} \mathrm{HCl}$ to the mixtures incubated for $1.5 \mathrm{hr}$ at $37^{\circ} \mathrm{C}$. After centrifugation at $10,000 \times g$ for $20 \mathrm{~min}$, the supernatant was applied onto an Amberlite XAD-2 column $(0.6 \times 3 \mathrm{~cm}, 48-100 \mathrm{mesh})$. The column was washed with $5 \mathrm{ml}$ of deionized water and then $\mathrm{B}_{12}$ compounds were eluted with $2 \mathrm{ml}$ of $25 \%$ ethanol $(\mathrm{v} / \mathrm{v})$. The identification of cobalamins was done with paper electrophoresis.

When $\left[{ }^{14} \mathrm{C}\right] \mathrm{ATP}$ was used, the complete reaction mixture contained cobalamin analog $0.1 \mu \mathrm{mol}$, homocysteine $5 \mu \mathrm{mol},\left[{ }^{14} \mathrm{C}\right] \mathrm{ATP} 0.4 \mu \mathrm{mol}(0.25 \mu \mathrm{Ci}), \mathrm{MgCl}_{2} 12.5$ $\mu \mathrm{mol}, \mathrm{KCl} 12.5 \mu \mathrm{mol}$, DTT $1.25 \mu \mathrm{mol}, \mathrm{FMNH}_{2} 0.1 \mu \mathrm{mol}$, Tris- $\mathrm{HCl}$ buffer 100 $\mu \mathrm{mol}$ and cell-free extracts (protein, $c a .0 .4 \mathrm{mg}$ ) in a total volume of $0.5 \mathrm{ml}$. $\mathrm{FMNH}_{2}$ and $\left[{ }^{14} \mathrm{C}\right] \mathrm{ATP}$ were added after gas substitution into $\mathrm{H}_{2}$. After incubation 
at $37^{\circ} \mathrm{C}$ for $1 \mathrm{hr}$ the reaction was terminated by adding $0.5 \mathrm{ml}$ of $1 \mathrm{~N} \mathrm{HCl}$. In order to adjust $\mathrm{pH}$ and change the color of cobalamins, which influence the efficiency of counting radioactivity, $1 \mathrm{ml}$ of $1 \mathrm{M} \mathrm{K}_{2} \mathrm{HPO}_{4}$ was added. After Amberlite XAD-2 column chromatography in a way similar to the above experiment with nonlabeled ATP, the eluates were counted in $10 \mathrm{ml}$ of Bray's solution in a Packard Tri-Carb liquid scintillation spectrometer (Model 3320-515). Since quenching of radioactivity by cobalamin was very high, the correction was made by examining the recovery of the radioactivity of known amount of $\left[{ }^{14} \mathrm{C}\right] \mathrm{ATP}$ added after counting.

Extraction and partial purification of $\left[{ }^{57} \mathrm{Co}\right] \mathrm{B}_{12}$ compounds from the cells. The cells containing $\left[{ }^{57} \mathrm{Co}\right] \mathrm{B}_{12}$ were suspended in $80 \%$ ethanol (one $\mathrm{ml}$ per the cells obtained from one $\mathrm{ml}$ of the culture). The suspension was refluxed for $20 \mathrm{~min}$ in the dark, all subsequent operations being carried out in the dark. The ethanol extract was centrifuged at $10,000 \times g$ for $20 \mathrm{~min}$. The precipitate was washed with the same volume of $80 \%$ ethanol as that of the extract and the suspension was centrifuged. The supernatants were combined and evaporated to dryness with a rotary evaporator. To the residue $2 \mathrm{ml}$ of carrier $\mathrm{B}_{12}$ (about $70 \mu \mathrm{g}$ each of cyano-, hydroxo-, methyl-, adenosyl-cobalamin) was added and the solution was applied to an Amberlite XAD-2 column. The column was washed with $3 \mathrm{ml}$ of deionized water and then $\mathrm{B}_{12}$ compounds were eluted with $3 \mathrm{ml}$ of $25 \%$ ethanol. The eluate was evaporated to dryness with a rotary evaporator. The residue was dissolved in one drop of deionized water $(c a .0 .05 \mathrm{ml})$ and used as the sample $(10 \mu \mathrm{l}$ for each run) for paper electrophoresis. The radioactivity of $\left[{ }^{57} \mathrm{Co}\right] \mathrm{B}_{12}$ compounds was measured using a well-type scintillation counter (Fuji Denki Co., ATS-700).

Extraction of $\left[{ }^{57} \mathrm{Co}\right] \mathrm{B}_{12}$ compounds from cells and cell-free extracts. $P$. ruber was cultivated for $95 \mathrm{hr}$ in $100 \mathrm{ml}$ of the medium containing $\left[{ }^{57} \mathrm{Co}\right] \mathrm{B}_{12}$ instead of cobaltous ion by inoculating the cells cultured for $40 \mathrm{hr}$ in a cobalt-deficient medium. The cells thus obtained were divided into two parts. From the one part of the cells $\mathrm{B}_{12}$ compounds were directly extracted with $80 \%$ ethanol, while from the other part the cell-free extracts were first prepared and $B_{12}$ compounds then extracted. After measuring the radioactivity of the $\mathrm{B}_{12}$ extracts in order to calculate the extraction efficiency, the samples for paper electrophoresis were obtained by the method described above.

Determination of the forms of $B_{12}$ compounds with paper electrophoresis. Paper electrophoresis was carried out at $800 \mathrm{~V}$ for $2 \mathrm{hr}$ on Whatman $3 \mathrm{MM}$ filter paper $(2 \times 40 \mathrm{~cm})$ with a Toyo type C-II paper electrophoretic apparatus in $0.52 \mathrm{~N}$ acetic acid or $0.1 \mathrm{~N}$ acetate buffer $(\mathrm{pH} 3.4)$ in the dark (1). The paper was cut at $0.5 \mathrm{~cm}$ intervals. The radioactivity of $\left[{ }^{57} \mathrm{Co}\right] \mathrm{B}_{12}$ of each piece was measured.

\section{RESULTS}

\section{Time course of growth and $B_{12}$-dependent methionine synthase activities}

Bacterial growth on $2 \%$ methanol in conventional cultivation reached a maximum after about $60 \mathrm{hr}$ (Fig. 1). The time courses of the specific activities of 5 - 


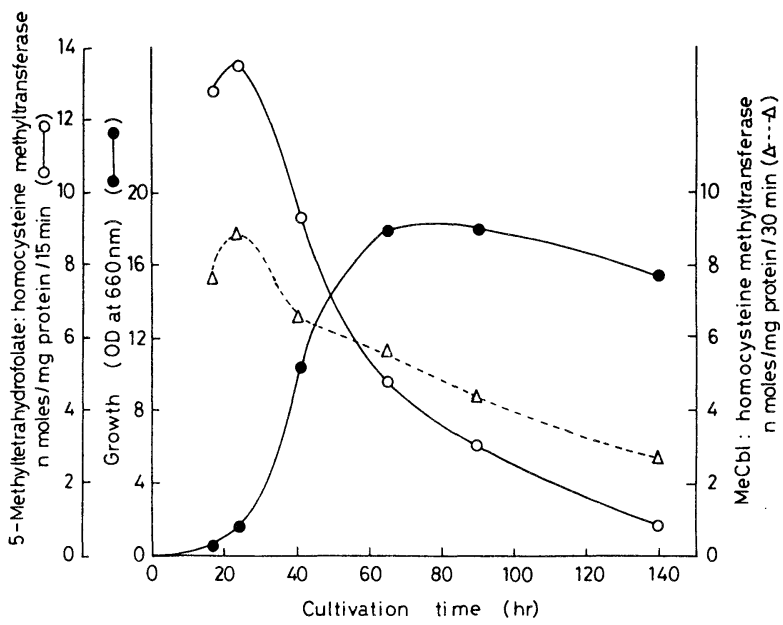

Fig. 1. Time course of growth and specific activities of 5-methyltetrahydrofolate: homocysteine methyltransferase and methylcobalamin: homocysteine methyltransferase of $P$. ruber.

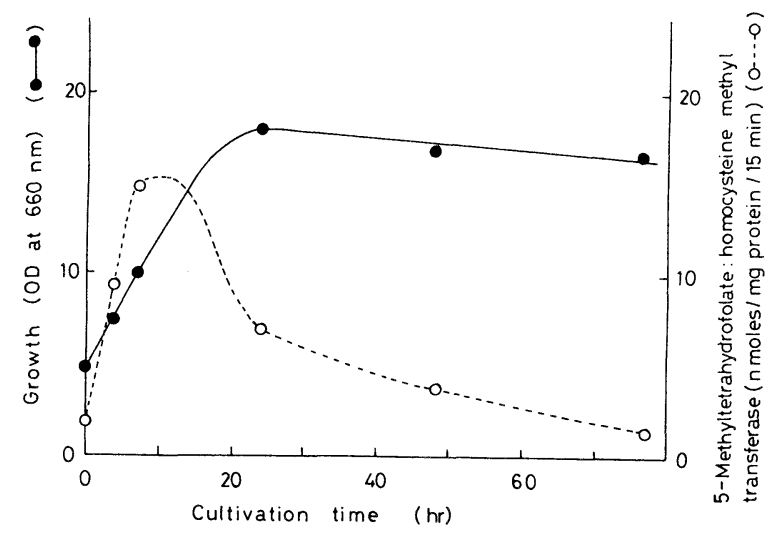

Fig. 2. Time course of growth and specific activity of 5-methyltetrahydrofolate: homocysteine methyltransferase of $P$. ruber cultured in "two-step cultivation method."

methyltetrahydrofolate: homocysteine methyltransferase and methylcobalamin: homocysteine methyltransferase are shown in Fig. 1. Both specific activities were high in the early phases of bacterial growth (i.e. $13.5 \mathrm{nmol} / \mathrm{mg} / 15 \mathrm{~min}$ for the former and $9.0 \mathrm{nmol} / \mathrm{mg} / 30 \mathrm{~min}$ for the latter) and decreased with cultivation time, but it is noteworthy that the decrease of 5-methyltetrahydrofolate: homocysteine methyltransferase activity was more drastic than that of methylcobalamin: homocysteine methyltransferase.

Figure 2 shows the time courses of the growth and the specific activity of 5Vol. 26, No. 6, 1980 
methyltetrahydrofolate: homocysteine methyltransferase by a two-step cultivation method. The lag phase of the bacterial growth was scarcely observed and the logarithmic phase continued until about $20 \mathrm{hr}$ cultivation. The enzyme activity was high in the cells of the early phases of bacterial growth. The maximal specific activity reached $c a .15 \mathrm{nmol} / \mathrm{mg}$ protein $/ 15 \mathrm{~min}$ in the cells after about $10 \mathrm{hr}$ cultivation, which well corresponds to the activity obtained from the cells in conventional cultivation (Fig. 1). Therefore, the two-step cultivation method was employed for the greater part of this study.

\section{Changes of the forms of intracellular cobalamins}

The enzyme activity decreased drastically and became very low at the stationary phase of the bacterial growth (Fig. 2). Under these circumstances, methylcobalamin in the cells almost disappeared and most $B_{12}$ compounds consisted of adenosylcobalamin(1). In order to examine how $\mathrm{B}_{12}$-forms change when such stationary phase cells would multiply by transferring to a fresh medium, $P$. ruber was cultivated in the medium containing $\left[{ }^{57} \mathrm{Co}\right]$ cyanocobalamin until the stationary phase of growth and then transferred to the fresh medium (MATERIALS AND METHODS (B)). $B_{12}$ compounds extracted from the cells were examined by
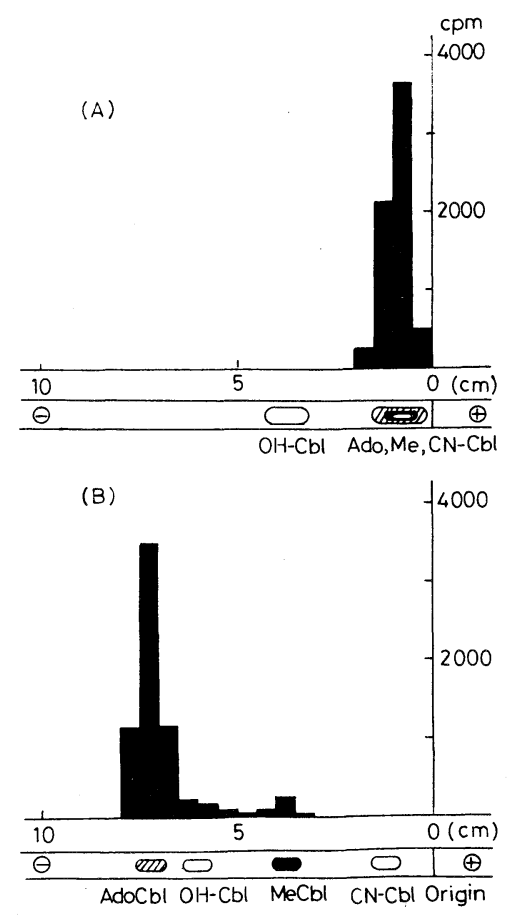

Fig. 3. A typical radioactigraph after paper electrophoresis of $\left[{ }^{57} \mathrm{Co}\right]$ cobalamins extracted from the cells in $0.1 \mathrm{~N}$ acetate buffer $(\mathrm{pH} 3.4)(\mathrm{A})$ and $0.52 \mathrm{~N}$ acetic acid (B). 
paper electrophoresis. Figure 3 shows a typical radioactigraph of $\left[{ }^{57} \mathrm{Co}\right] \mathrm{B}_{12}$ compounds extracted from the cells. As shown in Fig. 3 (A), no hydroxocobalamin was detected in the sample by paper electrophoresis in $0.1 \mathrm{~N}$ acetate buffer ( $\mathrm{pH} 3.4$ ). Paper electrophoresis in $0.52 \mathrm{~N}$ acetic acid revealed that the sample contained adenosylcobalamin and a small amount of methylcobalamin (Fig. 3 (B)).

The samples extracted from the cells in each cultivation time were treated similarly to the sample in Fig. 3. From the figures thus obtained, the percentages of the radioactivities of methyl- or adenosyl-cobalamin to those of total cobalamins were calculated for each sample and are summarized in Fig. 4. Almost all cobalamins in the inoculated cells at zero cultivation time were present as adenosylcobalamin, which was gradually converted to methylcobalamin during the logarithmic phase of growth. The conversion reached a level of about $40 \%$ around the middle logarithmic phase of the bacterial growth. After the late logarithmic phase, methylcobalamin was again converted into adenosylcobalamin.

\section{Forms of $B_{12}$ compounds in cells and cell-free extracts}

We could not detect any hydroxo- and sulfito-cobalamin in the extracts from the cells. Those cobalamins might be detected in the $\mathrm{B}_{12}$-extracts from the cell-free extracts. To test this possibility, $\left[{ }^{57} \mathrm{Co}\right] \mathrm{B}_{12}$ compounds were extracted from cells and cell-free extracts and the patterns of $\mathrm{B}_{12}$ forms were compared in paper electrophoresis. As shown in Fig. 5 (A) and (B), neither hydroxocobalamin nor sulfitocobalamin was detected in the extracts from the cells and the cell-free extracts. When the samples were exposed to light, all the $\mathrm{B}_{12}$ compounds were converted into hydroxocobalamin (Fig. 5 (C) and (D)).

\section{Conversion of methylcobalamin into adenosylcobalamin in vitro}

Since the interconversion of methylcobalamin and adenosylcobalamin is probable from the results of Fig. 4, we examined the possibility of the

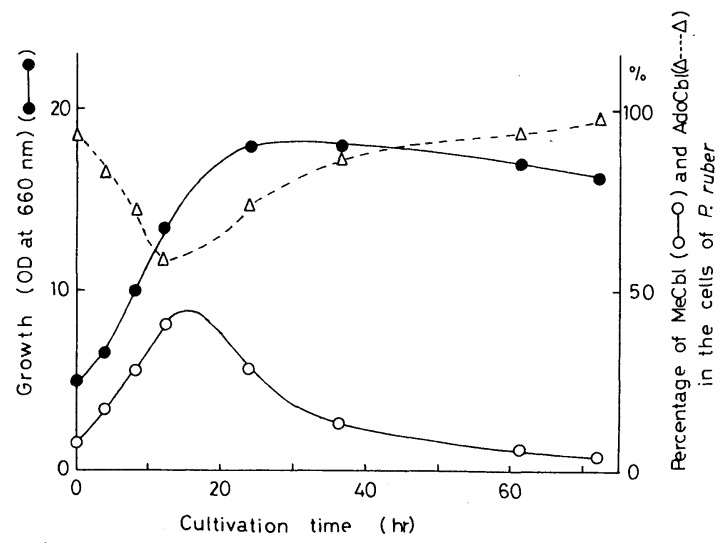

Fig. 4. Time course of growth and changes of cobalamin-forms of P. ruber. 

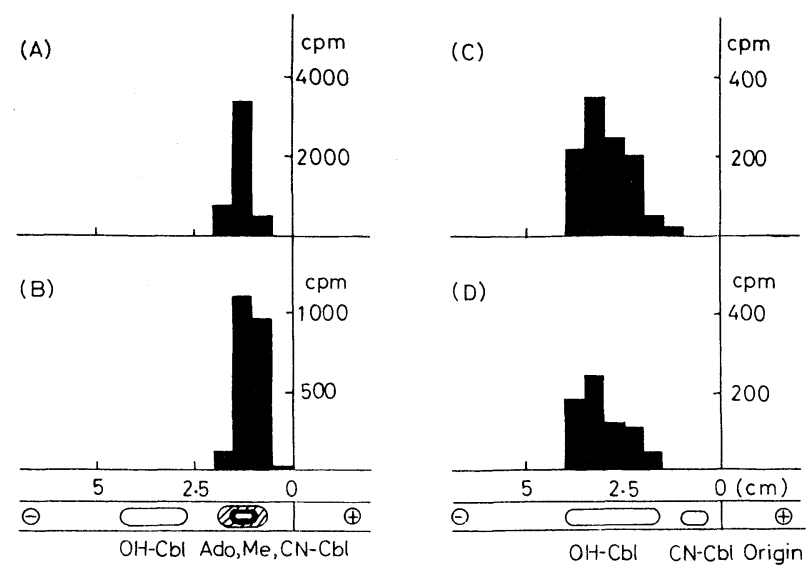

Fig. 5. Actigraphs after paper electrophoresis of the samples obtained from cells (A) and cell-free extracts (B) of $P$. ruber in $0.1 \mathrm{~N}$ acetate buffer ( $\mathrm{pH} 3.4)$. (C) and (D) were obtained by exposing (A) and (B), respectively, to light.

Table 1. Requirements for the conversion of methylcobalamin into adenosylcobalamin.

\begin{tabular}{lc}
\hline Reaction mixture & $\begin{array}{r}{\left[{ }^{14} \mathrm{C}\right] \text { Adenosylcobalamin formed }} \\
(\mathrm{nmol} / \mathrm{mg} \text { protein/min })\end{array}$ \\
\hline Complete & 0.20 \\
- Methylcobalamin & 0 \\
- Homocysteine & 0.07 \\
- $\mathrm{FMNH}_{2}$ & 0 \\
\hline
\end{tabular}

interconversion by the in vitro enzymatic reaction. Table 1 shows that adenosylcobalamin was enzymatically formed from methylcobalamin. For the reaction, homocysteine and $\mathrm{FMNH}_{2}$ were required.

The rates of conversion of various cobalamin analogs into adenosylcobalamin are shown in Table 2. Methylcobalamin was most effective for this reaction. Hydroxo- and cyano-cobalamin were also converted well into adenosylcobalamin. Propyl- and adenosyl-cobalamins had low but significant conversion rates. This adenosylation was also confirmed by paper electrophoresis (Fig. 6, Sample 1). Adenosylcobalamin could be formed in the absence of homocysteine, when hydroxocobalamin was used.

Effect of propylation on the activities of methyltransferase and adenosyltransferase

When methylcobalamin is used for adenosylation, it is plausible that the methyl group of the compound is transferred to homocysteine by methyltransferase. In order to examine whether this reaction is catalyzed by 5-methyltetrahy- 
Table 2. Rates of conversion of various cobalamin analogs to adenosylcobalamin.

\begin{tabular}{lc}
\hline Substrates & $\begin{array}{c}{\left[{ }^{14} \mathrm{C}\right] \text { Adenosylcobalamin formed }} \\
(\mathrm{nmol} / \mathrm{mg} \text { protein } / \mathrm{min})\end{array}$ \\
\hline Methylcobalamin & 0.18 \\
Hydroxocobalamin & 0.16 \\
Cyanocobalamin & 0.15 \\
Adenosylcobalamin & 0.05 \\
Propylocobalamin & 0.10 \\
\hline
\end{tabular}

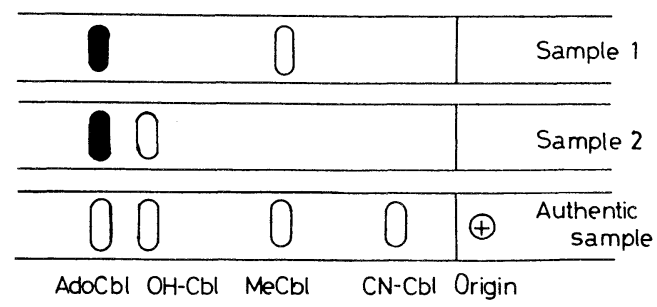

Fig. 6. Paper electrophoretic properties of samples obtained by the adenosylation. The compounds used as substrates were ATP and methylcobalamin in sample 1, ATP and hydroxocobalamin in sample 2 .

Table 3. Effect of chemical propylation on methyl group transfer and adenosylation reaction.

\begin{tabular}{|c|c|c|c|}
\hline \multirow{2}{*}{ Conditions } & \multicolumn{2}{|c|}{$\left[{ }^{14} \mathrm{C}\right]$ Methionine formed } & \multirow{2}{*}{$\begin{array}{c}{\left[{ }^{14} \mathrm{C}\right] \text { Adenosylcobal- }} \\
\text { amin formed } \\
\text { from }\left[{ }^{14} \mathrm{C}\right] \mathrm{ATP}\end{array}$} \\
\hline & $\begin{array}{l}\text { from } 5-\left[{ }^{14} \mathrm{C}\right] \text { methyl- } \\
\text { tetrahydrofolate }\end{array}$ & $\begin{array}{l}\text { from }\left[{ }^{14} \mathrm{C}\right] \text { methyl- } \\
\text { cobalamin }\end{array}$ & \\
\hline & \multicolumn{3}{|c|}{$(\mathrm{nmol} / \mathrm{mg}$ protein $/ \mathrm{min})$} \\
\hline Propylated enzyme & 0.04 & 0.30 & 0.16 \\
\hline $\begin{array}{l}\text { Propylated enzyme } \\
\quad+\text { light }\end{array}$ & 0.26 & 0.27 & 0.13 \\
\hline Non-propylated enzyme & 0.41 & 0.32 & 0.17 \\
\hline $\begin{array}{l}\text { Non-propylated enzyme } \\
+ \text { light }\end{array}$ & 0.41 & 0.28 & 0.12 \\
\hline
\end{tabular}

drofolate: homocysteine methyltransferase or by methylcobalamin: homocysteine methyltransferase, the enzyme was propylated with 1-iodopropane. The propylated and non-propylated (control) enzymes with or without exposure to light were assayed for methyltransfer and the adenosylation reaction. Table 3 summarizes the Vol. 26, No. 6, 1980 
results. Only the reaction with 5-methyltetrahydrofolate: homocysteine methyltransferase was inhibited by propylation and the activity was considerably restored by exposure to light. In contrast, no such effect of light was observed with the nonpropylated enzyme of the control. The activity change of methylcobalamin: homocysteine methyltransferase coincided very well with that of the enzyme systems catalyzing adenosylation.

\section{DISCUSSION}

The high content of methylcobalamin in younger tissues of human brain or liver has been reported by Linnell (14). The content of methylcobalamin in P. ruber or Streptomyces olivaceus was also high in the early phases of bacterial growth $(1,15)$. The high specific activity of 5-methyltetrahydrofolate: homocysteine methyltransferase during logarithmic phases of the growth (Fig. 1) well corresponds to the high content of methylcobalamin during these phases. Similar results, such as the maximal specific activity $15 \mathrm{nmol} / \mathrm{mg}$ protein $/ 15 \mathrm{~min}$, were obtained by the "two-step cultivation method" (Fig. 2) (10). This "two-step cultivation method" seems to be very useful for obtaining sufficient numbers of cells in the case where an enzyme has a high specific activity in an early phase of microbial growth, while in conventional culture the early phase cells would be obtained only by a large-scale cultivation.

By the two-step cultivation method, we could find changes of $\mathrm{B}_{12}$-forms in the cells during the cultivations (Fig. 4). The formation of methylcobalamin by the conversion of adenosylcobalamin was confirmed, since $\left[{ }^{57} \mathrm{Co}\right]$ methylcobalamin was formed in an early phase of the growth under the conditions of little de novo $\mathrm{B}_{12}$ formation by cultivating the cells that contained $\mathrm{B}_{12}$ compounds mostly in the form of $\left[{ }^{57} \mathrm{Co}\right]$ adenosylcobalamin in a fresh medium for the second culture. The reverse conversion from methylcobalamin to adenosylcobalamin was also observed in the later stages of the growth. $\mathrm{B}_{12}$ compounds were extracted almost quantitatively from the cells and the cell-free extracts, and no hydroxocobalamin was detected in both $\mathrm{B}_{12}$ extracts. Therefore, amounts of $\mathrm{B}_{12}$ compounds other than methyl- and adenosyl-cobalamin were negligible, if any. The stable existence of sulfitocobalamin in the cells is not likely, at least in P. ruber, although sulfitocobalamin was isolated from partially purified methionine synthase in $E$. $\operatorname{coli}(4,5)$.

The demonstration of conversion of methylcobalamin into adenosylcobalamin in vitro (Table 1, Fig. 6) suggests that the reaction is catalyzed by methyltransferase (4) and adenosyltransferase (16). It is noteworthy that methylcobalamin was the best compound among various $B_{12}$ analogs for the enzymatic conversion to adenosylcobalamin (Table 2). All the $\mathrm{B}_{12}$ compounds tested were effective in different degrees for adenosylation, and adenosylcobalamin was also converted to labeled compounds by the exchange reaction. These findings seem to show that there are differences in the reductive cleavage or cleavage mode depending upon 


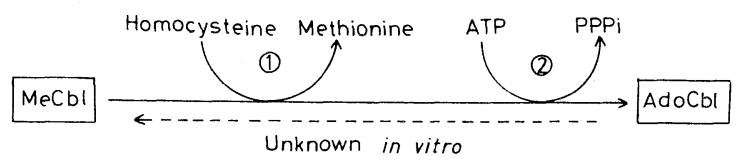

Scheme 1. Formation of adenosylcobalamin from methylcobalamin.

the nature of the upper ligand of cobalamins.

It is known that cobalamin-dependent methyltransferase from $E$. coli gives an inhibited propylcobalamin-enzyme by propylation with 1-iodopropane and that the inactive propylcobalamin-enzyme can be reactivated by exposure to visible light $(4,17,18)$. On the other hand, methyl group transfer from methylcobalamin to homocysteine is not affected by propylation $(17,19)$.

As shown in Scheme 1, the first step of adenosylation in the case of methylcobalamin is considered to be catalyzed by methyltransferase and the second step by adenosyltransferase (16). The first step of the reaction was not inhibited at all by propylation with 1-iodopropane (Table 3 ). The highly purified methionine synthase from $P$. ruber catalyzed methyl group transfer from 5-methyltetrahydrofolate as well as methylcobalamin to homocysteine, and it was thus assumed that both reactions were catalyzed at separate catalytic sites on the same protein $(12,20)$. This was confirmed by the fact that only methyl group transfer from 5-methyltetrahydrofolate to homocysteine was inhibited by the propylation (Table 3). Since in vitro adenosylcobalamin formation from methylcobalamin was not influenced by propylation, it is plausible that the first step of the reaction is catalyzed by methylcobalamin: homocysteine methyltransferase (Scheme 1- (1)). Both specific activities of 5-methyltetrahydrofolate: homocysteine methyltransferase and methylcobalamin: homocysteine methyltransferase showed similar patterns, but the latter was inactivated more slowly than the former (Fig. 1). This slower inactivation of the latter enzyme, i.e. methylcobalamin: homocysteine methyltransferase might facilitate the decomposition of methylcobalamin released from the active site of the former enzyme which would be inactivated faster with the cultivation time. The accumulation of adenosylcobalamin in the cells thus might be promoted in collaboration with adenosyltransferase whose activity is relatively high in comparison with other sources $(21,22)$. The reverse reaction from adenosylcobalamin into methylcobalamin in vitro might be catalyzed by an enzyme resembling holoenzyme synthetase obtained from $E$. coli (23), but this remains to be demonstrated.

This work was supported in part by a grant (No. 456062) from the Ministry of Education, Science and Culture, Japan.

\section{REFERENCES}

1) Sato, K., Ueda, S., and Shimizu, S. (1977): Form of vitamin $B_{12}$ and its role in a methanol-utilizing bacterium, Protaminobacter ruber. Appl. Environ. Microbiol., 33, 515-521.

Vol. 26, No. 6, 1980 
2) Sato, K., Ueda, S., and Shimizu, S. (1976): Methylmalonyl-CoA mutase in a methanolutilizing bacterium, Protaminobacter ruber. FEBS Lett., 71, 248-250.

3) Ueda, S., Sato, K., and Shimizu, S. (1978): Role of vitamin $B_{12}$ and enzymes related to methylmalonyl-CoA mutase in a methanol-utilizing bacterium, Protaminobacter ruber. J. Nutr. Sci. Vitaminol., 24, 477-489.

4) Taylor, R. T., and Weissbach, H. (1973): $N^{5}$-Methyltetrahydrofolate-homocysteine methyltransferase, in The Enzymes, ed. by Boyer, P. D., Academic Press, New York and London, Vol. 9, pp. 121-165.

5) Ertel, R., Brot. N., Taylor, R., and Weissbach, H. (1968): Studies on the nature of the bound cobamide in $E$. coli $N^{5}$-methyltetrahydrofolate-homocysteine transmethylase. Arch. Biochem. Biophys., 126, 353-357.

6) Taylor, R. T., and Weissbach, H. (1969): Escherichia coli B $N^{5}$-methyltetrahydrofolatehomocysteine cobalamin methyltransferase: Activation with $S$-adenosyl-L-methionine and the mechanism for methyl group transfer. Arch. Biochem. Biophys., 129, 745-766.

7) Keresztesy, J. C., and Donaldson, K. O. (1961): Synthetic prefolic A. Biochem. Biophys. Res. Commun., 5, 286-288.

8) Smith, E. L., Mervyn, L., Johnson, A. W., and Shaw, N. (1962): Partial synthesis of vitamin $\mathrm{B}_{12}$ coenzymes and analogues. Nature, 194, 1175.

9) Taylor, R. T., and Weissbach, H. (1967): $N^{5}$-Methyltetrahydrofolate-homocysteine transmethylase. Partial purification and properties. J. Biol. Chem., 242, 1502-1508.

10) Sato, K., and Shimizu, S. (1979): The conditions for bacteriochlorophyll formation and the ultrastructure of a methanol-utilizing bacterium, Protaminobacter ruber, classified as non-photosynthetic bacteria. Agric. Biol. Chem., 43, 1669-1675.

11) Sato, K., Hiei, E., Shimizu, S., and Abeles, R. H. (1978): Affinity chromatography of $N^{5}$-methyltetrahydrofolate-homocysteine methyltransferase on a cobalamin-Sepharose. FEBS Lett., 85, 73-76.

12) Shimizu, S., and Sato, K. (1975): Methionine synthesis, in Seikagaku Jikken Koza, Bitamin To Hokoso (Ge), Tokyo Kagaku Dojin Co., Vol. 13, pp. 471-476.

13) Hiei, E., Sato, K., and Shimizu, S. (1979): Reactivity of vitamin $B_{12}$-dependent apomethionine synthetase with some derivatives of vitamin $B_{12}$ and its application to affinity chromatography. Vitamins (in Japanese), 53, 127-134.

14) Linnell, J. C. (1975): The fate of cobalamins in vivo, in Cobalamin, ed. by Babior, B. M., John Wiley \& Sons, New York, London, Sydney and Tronto, pp. 287-333.

15) Sato, K., Shimizu, S., and Fukui, S. (1971): Studies on the corrinoids and porphyrins in Streptomycetes. Part III. Influence of cultural conditions on the forms of corrinoids produced by Streptomyces olivaceus. Agric. Biol. Chem., 35, 333-337.

16) Mudd, S. H. (1973): $B_{12 \mathrm{~s}}$ adenosyltransferase, in The Enzymes, ed. by Boyer, P. D., Academic Press, New York and London, Vol. 8, pp. 144-154.

17) Taylor, R. T., and Weissbach, H. (1967): $N^{5}$-methyltetrahydrofolate-homocysteine transmethylase. Propylation characteristics with the use of a chemical reducing system and purified enzyme. J. Biol. Chem., 242, 1509-1516.

18) Taylor, R. T., Whitfield, C., and Weissbach, H. (1968): Chemical propylation of vitamin $\mathrm{B}_{12}$ transmethylase: Anomalous behavior of $S$-adenosyl-D-methionine. Arch. Biochem. Biophys., 125, 240-252.

19) Ohmori, H., Sato, K., Shimizu, S., and Fukui, S. (1971): Studies on the corrinoids and porphyrins in Streptomycetes. Part IV. Confirmation of a cobalamin-dependent methionine synthesis system in Streptomyces olivaceus. Agric. Biol. Chem., 35, 338-343.

20) Sato, K., Hiei, E., and Shimizu, S. (1979): Purification of vitamin $B_{12}$-dependent 
methionine synthetase from Protaminobacter ruber by affinity chromatography with a cobalamin-Sepharose. Vitamins (in Japanese), 53, 397-401.

21) Vitols, E., Walker, G. A., and Huennekens, F. M. (1966): Enzymatic conversion of vitamin $\mathrm{B}_{12 \mathrm{~S}}$ to a cobamide coenzyme, $\alpha$-(5,6-dimethylbenzimidazolyl)deoxyadenosylcobamide (adenosyl- $\mathrm{B}_{12}$ ). J. Biol. Chem., 241, 1455-1461.

22) Fenton, W. A., and Rosenberg, L. E. (1978): Mitochondrial metabolism of hydroxocobalamin. Synthesis of adenosylcobalamin by intact rat liver mitochondria. Arch. Biochem. Biophys., 189, 441-447.

23) Brot, N., and Weissbach, H. (1966): The role of cobalamins in methionine synthesis. Enzymatic formation of holoenzyme. J. Biol. Chem., 241, 2024-2028. 